\title{
Presentation by Evgeny Zagaynov
}

\author{
Director of the Legal Department of the Ministry of Foreign Affairs, \\ Russian Federation
}

It is a great honour and pleasure to be back in New York and to take part in today's discussion. I wish to thank the organizers of this event for giving me the chance to address this meeting. After I received the invitation, a major event took place in my life; I would like to take this opportunity to express my sincere gratitude to the members of the International Law Commission for the trust that they have placed in me by electing me to join their ranks. I will endeavour to live up to that trust.

Today, however, I intend to follow my original plan and to speak in my capacity as Director of the Legal Service of the Ministry of Foreign Affairs of the Russian Federation, particularly since I have yet to commence work as a member of the Commission.

This year marks the seventieth anniversary of the Commission. The idea of codifying international law, however, is much older and dates back centuries. Although it has evolved over that time, its goal has always been to create a more just world order and to prevent war and conflict.

As the representative of the Russian Federation, I would like to say a few words about the contribution that has been made to the Commission's work by eminent international jurists from my country: Vladimir Mikhailovich Koretsky, Grigory Ivanovich Tunkin, Nikolai Aleksandrovich Ushakov and Roman Anatolyevich Kolodkin. The latter prepared three reports on the immunity of State officials from foreign criminal jurisdiction when he was Special Rapporteur for the topic, prior to Escobar Hernández. ${ }^{1}$

The Commission's achievements would not have been possible without the professionalism and dedication of the Secretariat. Today, we pay tribute to the efforts of many generations of colleagues who have participated in that work.

The relationship between the Commission and the Sixth Committee is a subject of paramount importance. The Commission, although a subsidiary body of the General Assembly, enjoys a high degree of autonomy, while the general political guidance from the Sixth Committee provides insight into the

1 Roman A. Kolodkin, 'Preliminary report on immunity of State officials from foreign criminal jurisdiction' [2008] II(1) ILC Ybk 157; 'Second report on immunity of State officials from foreign criminal jurisdiction' [2010] II(1) ILC Ybk 395; and 'Third report on immunity of State officials from foreign criminal jurisdiction' [2011] II(1) ILC Ybk 223. 
needs of States and what they expect from the Commission's work and helps to set the necessary benchmarks.

When recalling the Commission's achievements, we often evoke the 196os and 1970s. At that time, the Commission produced texts and reports that would become the basis for a number of key international legal instruments. Those successes were, in part, a result of its having set the bar high from the outset in the choice of topics for its long-term programme of work.

The Commission examined the most important and topical issues of international law in the first decades of its existence. As a result, in later years, the number of conventions adopted on the basis of its work substantially declined.

Does that mean that there is less demand for its work? I do not believe so; the Commission is currently considering a number of important topics. It is true, however, that the formulation of its programme of work is taking on growing significance. How a topic is formulated will determine the final outcome of the Commission's work, whether or not its conclusions are favourably received and supported by States and, subsequently, whether or not a decision is made to draft a convention. In precisely that regard, a balance must be struck between the demands of States and the independence of the Commission's members.

How can the Commission avoid working on topics that subsequently turn out not to reflect the needs of States? It is well known that the procedure for selecting topics has undergone changes. Since 1992, a mechanism has been in place for designating members of the Commission to write short outlines and explanatory summaries on topics included in a pre-selected list. ${ }^{2}$ Under article 17 of the Commission's statute, Member States, the General Assembly and other organs of the United Nations may submit proposals to the Commission regarding the progressive development of international law and its codification. In its early years, the Commission received numerous proposals and special tasks from the General Assembly, but in more recent times they have become fewer in number. It might be worthwhile trying to revive that practice.

Consideration should be given to how to make more effective use of the available mechanisms for including topics in the Commission's programme of work. Perhaps a special discussion should be held on how to improve the existing procedure for selecting and then working on topics. One option, in our view, could be to set up a mechanism under which topics for consideration by the Commission would be agreed upon and endorsed by the Sixth Committee.

Igor Ivanovich Lukashuk, a former member of the Commission, once remarked that it was a victim of its own early success: having codified the

2 See ILC, 'Report of the International Law Commission on the work of its forty-fourth session' [1992] II(2) ILC Ybk 1, 54 at para 369 . 
principal areas of international law through global conventions, it went on to study complex but marginal topics, which can result only in the generation of doctrinal material.

That said, many of the texts produced by the Commission in recent years, such as those on the responsibility of States for internationally wrongful acts, ${ }^{3}$ the responsibility of international organizations, ${ }^{4}$ and diplomatic protection, ${ }^{5}$ are highly relevant. That they are held up for years before the Sixth Committee or emerge from it without being followed up is not the Commission's doing. Rather, the responsibility lies with the Committee, in other words, with States. For one reason or another, they prefer not to have conventions in those areas. One result of this passivity is that, even without the "blessing" of States, courts are nevertheless beginning to invoke these texts, which they view as a part of customary law. ${ }^{6}$ They are even referring to texts that the Commission has yet to finalize. ${ }^{7}$

On occasion, one hears the view that a particular text produced by the Commission is so good that the input of States would only spoil it. I do not believe that is the right approach. If States cannot reach a decision on a given topic, one must assume that, unfortunately, the work on it is not yet complete.

In today's difficult circumstances, the Sixth Committee is one of the few United Nations organs to remain faithful to the principle of consensus. That is very valuable. One can hardly expect unanimity in the Committee regarding issues on which members of the Commission have been unable to reach agreement. Such situations should be avoided.

With regard to the important issue of the pace of the Commission's work, speed should not be a goal unto itself. It is well known that many of the Commission's landmark texts have been worked on for decades. For example, where a text has not elicited many responses from States after the first reading, it has at times been advisable to defer discussion on it for a year or two in order to gather more views. Not all governments are able to respond rapidly to the Commission's texts, but that does not mean that their views are unimportant.

3 UNGa Res 56/83 (12 December 2001).

4 ILC, 'Draft articles on the responsibility of international organizations' [2011] II(2) ILC YBK 40.

5 ILC, 'Draft articles on diplomatic protection' [2006] II(2) ILC YBK 24.

6 See, for example, and United Nations, 'Responsibility of States for internationally wrongful acts. Compilation of decisions of international courts, tribunals and other bodies' (2016) UN $\operatorname{Doc} \mathrm{A} / 71 / 8$ o.

7 See, e.g. Gabcikovo-Nagymaros Project (Hungary/Slovakia) (Merits) [1997] ICJ Rep 7, paras 47, 5 o, 52,79 and 83 . 
I should like to draw attention to another practical problem: the honoraria of Special Rapporteurs. The preparation of reports is a time-consuming process that also requires considerable intellectual effort. As you know, the Chair of the Commission and Special Rapporteurs used to receive honoraria. Then, in 2002, the General Assembly fundamentally changed the system, setting the level of honoraria for members of the Commission at one dollar. ${ }^{8}$ That decision was taken without consulting the Commission. Since then, the Commission has on more than one occasion called upon the General Assembly to revisit the issue. ${ }^{9}$ From the outset, our delegation has maintained that the matter must be resolved. We trust that dialogue between the General Assembly and the Commission will continue and that a practical solution will be found.

The work of codifying and progressively developing international law is an ongoing process. As long as humanity pursues its endeavours in different areas and strives for excellence and harmony, that work will continue to be vital and beneficial to the international community.

8 UNGA Res 56/272 (27 March 2002).

9 ILC, 'Report of the International Law Commission on the work of its fifty-fourth session' [2002] II(2) ILC Ybk 1, 102 at para 525-531; 'Report of the International Law Commission on the work of its fifty-fifth session' [2003] II(2) ILC Ybk 1, 101 at para 447; 'Report of the International Law Commission on the work of its fifty-sixth session' [2004] II(2) ILC Ybk 1, 120 at para 369; 'Report of the International Law Commission on the work of its fifty-seventh session' [2005] II(2) ILC Ybk 1, 92 at para 501; 'Report of the International Law Commission on the work of its fifty-eighth session' [2006] II(2) ILC Ybk 1, 187 at para 269; 'Report of the International Law Commission on the work of its fifty-ninth session' [2007] II(2) ILC Ybk 1, 100 at para 379; 'Report of the International Law Commission on the work of its sixtieth session' [2008] II(2) ILC Ybk 1, 148 at para 358; 'Report of the International Law Commission on the work of its sixty-first session' [2009] II(2) ILC Ybk 1, $15^{1}$ at para 24O; 'Report of the International Law Commission on the work of its sixty-second session' [2010] II(2) ILC Ybk 1, 203 at para 396; 'Report of the International Law Commission on the work of its sixty-third session' [2011] II(2) ILC Ybk 1, 178 at para 399; 'Report of the International Law Commission on the work of its sixty-fourth session' [2012] II(2) ILC Ybk 1, 87 at para 280; 'Report of the International Law Commission on the work of its sixty-fifth session' [2013] II(2) ILC Ybk 1, 79 at para 181; 'Report of the International Law Commission on the work of its sixty-sixth session' (2014) UN Doc A/69/10, para 281; 'Report of the International Law Commission on the work of its sixty-seventh session' (2015) UN Doc A/7o/10, para 299; 'Report of the International Law Commission on the work of its sixty-eighth session' (2016) UN Doc A/71/10, para 333; 'Report of the International Law Commission on the work of its sixty-ninth session' (2017) UN Doc $\mathrm{A} / 72 / 10$, para 282; and 'Report of the International Law Commission on the work of its seventieth session' (2018) UN Doc A/73/10, para 382 . 